\title{
Ultrahigh-temperature metamorphism of the Southern Marginal Zone of the Archean Limpopo Belt, South Africa
}

\author{
Toshiaki TsunogaE ${ }^{*}$, Takashi Miyano*, Dirk D. van ReEnen ${ }^{* *}$ and C. André SMit ${ }^{* *}$ \\ *Institute of Geoscience, University of Tsukuba, Ibaraki 305-8571, Japan \\ ${ }^{* *}$ Department of Geology, Rand Afrikaans University, P.O. Box 524, \\ Auckland Park 2006, South Africa
}

\begin{abstract}
We report ultrahigh-temperature $\left(T>950^{\circ} \mathrm{C}\right)$ peak metamorphic conditions for the Southern Marginal Zone of the Archean Limpopo Belt in South Africa. Pelitic granulites of the zone have a typical mineral assemblage of garnet + biotite + orthopyroxene + cordierite + quartz $+\mathrm{K}$-feldspar + plagioclase \pm sillimanite, to which the latest geothermobarometers are applicable. The revised $P-T$ conditions were obtained from a ternary feldspar geothermometer using antiperthitic feldspars in leucocratic granulite $\left(920-980^{\circ} \mathrm{C}\right)$, Al solubility in orthopyroxene in pelitic granulite $\left(970-1020^{\circ} \mathrm{C}\right)$, and a revised garnet- ${ }^{-}$orthopyroxene geothermometer corrected for retrograde $\mathrm{Fe}-\mathrm{Mg}$ exchange $\left(920^{-} 990^{\circ} \mathrm{C}\right)$. The estimated peak temperature of metamorphism is about $100^{\circ} \mathrm{C}$ higher than previously estimated based on conventional $\mathrm{Fe}-\mathrm{Mg}$ exchange geothermometers $\left(800-870^{\circ} \mathrm{C}\right)$, and indicates a high geothermal gradient of $\sim 35^{\circ} \mathrm{C} / \mathrm{km}$ in Archean continental lower crust.
\end{abstract}

\section{Introduction}

The Limpopo Belt of southern Africa is a classic example of a granulite-facies metamorphic complex (Mason, 1973 ) formed by the collision of low-grade granitegreenstone terranes of the Zimbabwe Craton in the north and the Kaapvaal Craton in the south during the late Archean (e.g. van Reenen et al., 1987; Roering et al., 1992). The belt has been traditionally subdivided into three zones on the basis of lithological and structural characteristics: the Southern Marginal Zone (SMZ), Central Zone, and Northern Marginal Zone (NMZ). Both the SMZ and NMZ are regarded high-grade equivalents of the adjacent low-grade Kaapvaal and Zimbabwe Craton lithologies. The SMZ (Fig. 1) is composed mainly of quartzo-feldspathic gneiss (including minor charnockite), mafic and pelitic granulites, and banded iron formations (e.g. Du Toit et al., 1983). On the other hand, charnockite and enderbite are major lithology of the NMZ (e.g. Tsunogae et al., 1992).

The Limpopo Belt has attracted the interest of many geologists and petrologists over the past two decades as one of the oldest regional granulite terranes in the world (ca. 2.7 Ga metamorphic age; Barton and van Reenen, 1992). The lack of large high-grade metamorphic ter-

T. Tsunogae, tsunogae@arsia.geo.tsukuba.ac.jp Corresponding author ranes older than 2.7 Ga may be due to the heat of the Archean mantle, which is likely to have lead to the melting of granitic, pelitic, and mafic materials in the lower to middle crust. This is consistent with the common occurrences of komatiite ( $>18$ wt. $\%$ bulk $\mathrm{MgO}$ ) in some Archean greenstone belts, although komatiite is distinctly uncommon in Proterozoic rocks and very rare in Phanerozoic formations (Condie, 1997). Available experimental data suggests that the temperature of komatiitic magma exceeded $1600^{\circ} \mathrm{C}$ at $20 \mathrm{kbar}$ (Jaques and Green, 1980). Therefore, most geologists agree that the dramatic decrease in the abundance of komatiite at the end of the Archean reflects a decrease in mantle temperature. Lack of blueschist (Ernst, 1972) and the relative abundance of tonalitic, trondhjemitic, and granodioritic (TTG) rocks with depleted yttrium and heavy rare-earths (Martin, 1993) in Archean cratons may also support a hot mantle environment. However, the temperature of the Archean mantle is not well known due to the lack of available samples of mantle and lower crust. The Limpopo granulites are a rare occurrence from which temperatures of 2.7 Ga lower crust can be estimated directly. Therefore, exact $P-T$ determination of the granulites is important in establishing the late-Archean geothermal gradient.

The peak metamorphic $P-T$ conditions of the SMZ have already been estimated by several authors using conventional geothermobarometers and mineral-phase equilibria (e.g. van Reenen, 1983; Tsunogae and Miyano, 


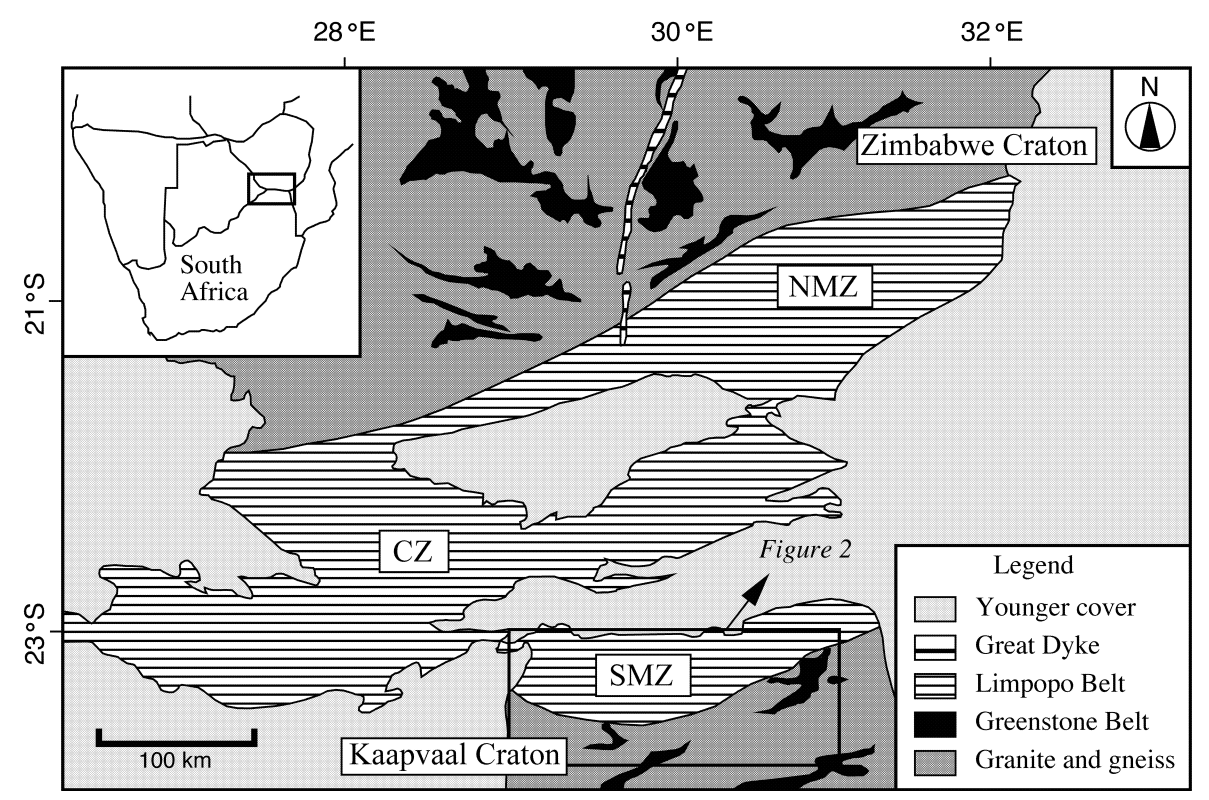

Figure 1. Location of the Southern Marginal Zone (SMZ), Central Zone $(\mathrm{CZ})$, and Northern Marginal Zone (NMZ) of the Limpopo Belt in southern Africa.

1989; Stevens and van Reenen, 1992a; Perchuk et al., 1996; 2000). The results indicate peak metamorphic conditions of $800-870^{\circ} \mathrm{C}$ and $7.5-8.5$ kbar. However, as pointed out by Frost and Chacko (1989) and Pattison et al. (2003), temperature estimates obtained by such conventional methods may be more than $100^{\circ} \mathrm{C}$ lower than the true peak temperatures in granulite-facies terranes due to the possible influence of retrograde cation exchange reactions between coexisting minerals (e.g. Fe-Mg exchange between garnet and pyroxene). The estimated $\sim 870^{\circ} \mathrm{C}$ peak temperature of SMZ metamorphism may therefore represent the minimum peak temperature in this zone.

In this study, the authors attempt to estimate the true peak metamorphic temperature of the SMZ using three geothermometric methods; (1) a ternary feldspar geothermometer using perthitic feldspar (Hokada, 2001), (2) Alsolubility in orthopyroxene (Hensen and Harley, 1990; Harley, 1998), and (3) a revised garnet-orthopyroxene geothermometer corrected for retrograde exchange (Pattison et al., 2003). The first two methods are regarded as being less influenced by retrograde metamorphism than conventional $\mathrm{Fe}-\mathrm{Mg}$ exchange geothermometers, and is therefore expected to be useful for reliably estimating peak temperatures in granulite-facies terranes (e.g. Tsunogae et al., 2002). The last method, proposed by Pattison et al. (2003), is also based on the Al-solubility in orthopyroxene, but is corrected for later $\mathrm{Fe}-\mathrm{Mg}$ exchange between garnet and orthopyroxene. Using the new $P-T$ data, we reevaluate the $P-T$ path of the SMZ in the Limpopo Belt. An accurate estimate of peak metamorphic temperatures in the Limpopo Belt is of particular importance to our understanding of the nature and evolution of
late-Archean granulite-facies metamorphism in thickened continental lower crust.

\section{General geology of the Limpopo SMZ}

A simplified geological map of the SMZ is shown in Figure 2. The rock sequences of the SMZ are subdivided into two major lithologies: gray migmatized tonalitic to trondhjemitic gneiss (Baviaanskloof Gneiss), and a sequence of metavolcanic and metasedimentary supracrustal rocks (Bandelierkop Formation). The latter sequence occurs as a series of discontinuous folded keels surrounded by the Baviaanskloof Gneiss. The lithological and structural characters of the Bandelierkop Formation, from which all samples in this study were obtained, are discussed in detail below. One of the most striking features of the SMZ is the presence of a retrograde metamorphic isograd (van Reenen, 1983; 1986) in the southern part of this zone (Fig. 2). This orthopyroxene isograd cuts across the structural trends of all lithologic units and can be followed for a distance of at least $150 \mathrm{~km}$ from east to west. The regions north and south of the isograd are referred to as the orthopyroxene zone and rehydration zone, respectively.

The Bandelierkop Formation is subdivided into three lithologies; ultramafic, mafic, and pelitic granulites. Pelitic granulite is brownish in color and exhibits welldeveloped gneissosity. The mineral assemblages of the granulite are variable, particularly across the orthopyroxene isograd. The pelitic assemblage in the orthopyroxene zone always contains orthopyroxene, whereas the pelite always contains anthophyllite and/or gedrite in the rehydration zone. Kreissig et al. (2000) obtained U-Pb mona- 


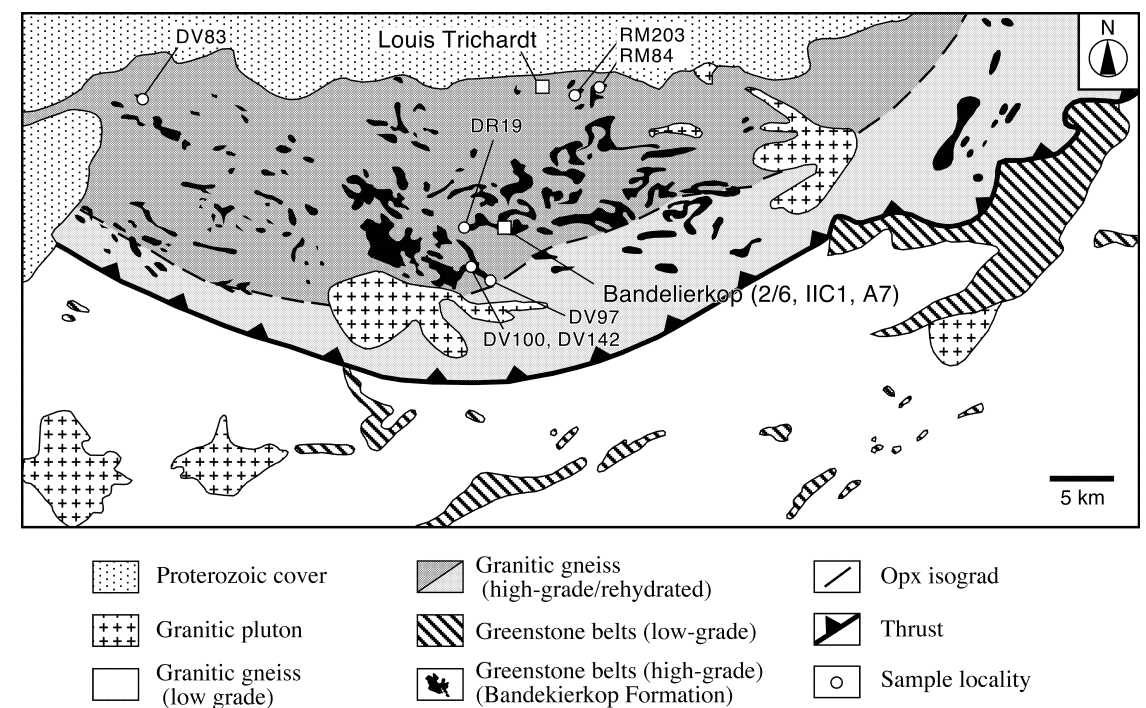

Figure 2. Geological map of the Southern Marginal Zone of the Limpopo Belt (after van Reenen et al., 1987) with the sample locality of pelitic granulites discussed in this paper. zite ages of $2691 \pm 7 \mathrm{Ma}$ for pelitic granulites from the Bandelierkop quarry (Fig. 2) in the SMZ. This result was interpreted as the age of peak metamorphism. Those authors also obtained a single zircon evaporation $\mathrm{Pb}-\mathrm{Pb}$ date of $2643 \pm 1 \mathrm{Ma}$ from a leucosome band at the same locality, which may indicate the time of decompression melting during exhumation.

There are several plutonic bodies intruding into the SMZ. The timing of emplacement of the syn-tectonic Matok Pluton (Fig. 2) has been determined to be $2671 \pm 2$ Ma by conventional $\mathrm{U}-\mathrm{Pb}$ analyses of zircons in intrusive charnoenderbite and enderbite (Barton et al., 1992). Kreissig et al. (2000) obtained similar $\mathrm{U}-\mathrm{Pb}$ monazite ages $(2663 \pm 4 \mathrm{Ma})$ for anatectic metapelitic xenoliths in the pluton.

\section{Petrography and mineral chemistry}

Samples of pelitic granulite and quartzo-feldspathic gneiss discussed in this study were carefully examined using microscope to identify mineral assemblages and reactions. Chemical analyses of minerals were performed by electron microprobe analyzers at Rand Afrikaans University (Oxford EDS) for feldspars in quartzo-feldspathic gneiss and Council for Geoscience, South Africa, (JEOL JXA733) for minerals in pelitic granulite. The data was obtained under conditions of $15 \mathrm{kV}$ accelerating voltage, using data processing by ZAF method. Halogen analyses have been done by electron microprobe at the Chemical Analysis Center of the University of Tsukuba (JEOL JXA8621) for biotite following the method described in Tsunogae et al. (2003a). Representative compositions of minerals in analyzed samples are given in Table 1.

\section{Pelitic granulite}

Pelitic granulites in the SMZ are subdivided into cordierite-free and cordierite-bearing assemblages. The cordierite-free pelitic granulite is quartzo-feldspathic and composed mainly of quartz, plagioclase, garnet, biotite, and $\mathrm{K}$ feldspar, with accessory amounts of zircon, apatite, and orthopyroxene (Figs. 3a and 4a). In this type of granulite (e.g. sample 2/6K), garnet is poikiloblastic (up to $2.9 \mathrm{~mm}$ ) and contains numerous inclusions of quartz, biotite, plagioclase, and opaque minerals (mainly magnetite). It is compositionally almandine-rich $\left(\mathrm{Alm}_{58^{-6}} \mathrm{Pyr}_{31^{-} 35} \mathrm{Grs}_{4-5}\right.$ $\left.\mathrm{Sps}_{2-3}\right)$. Orthopyroxene $(0.2-0.5 \mathrm{~mm})$ is not abundant, but if present also exhibits poikiloblastic textures including quartz and magnetite. Quartz, $\mathrm{K}$-feldspar, and plagioclase in the matrix are anhedral and coarse-grained (up to $1 \mathrm{~mm})$. The common occurrence of the orthopyroxene + $\mathrm{K}$-feldspar + quartz assemblage suggests that the granulite assemblage was formed by a prograde biotite breakdown reaction of the form

$$
\mathrm{Bt}+\mathrm{Qtz} \rightarrow \mathrm{Opx}+\mathrm{Kfs}+\text { vapor (or melt) }
$$

Mineral abbreviations are after Kretz (1983).

Cordierite-bearing pelitic granulite is the most dominant supracrustal lithology in the zone. Sample DV83, a typical cordierite-bearing pelitic granulite, is composed mainly of garnet $\left(\mathrm{Alm}_{54-57} \mathrm{Pyr}_{38^{-41}} \mathrm{Grs}_{3-4} \mathrm{Sps}_{1^{-2}}\right)$, biotite ( $\left.X_{\mathrm{Mg}}=0.69-0.75, \mathrm{Ti}=0.47-0.61 \mathrm{pfu}\right)$, orthopyroxene $\left(X_{\mathrm{Mg}}=0.62-0.66\right)$, quartz, plagioclase $\left(\mathrm{An}_{30-31}\right), \mathrm{K}$-feldspar $\left(\mathrm{Or}_{90-93}\right)$, and cordierite $\left(X_{\mathrm{Mg}}=0.84-0.86\right)$ as shown in AFM diagram (Fig. 4b). Sillimanite and spinel occur in some samples, and zircon, apatite, and monazite are present as accessory minerals. Orthopyroxene is medium- to 


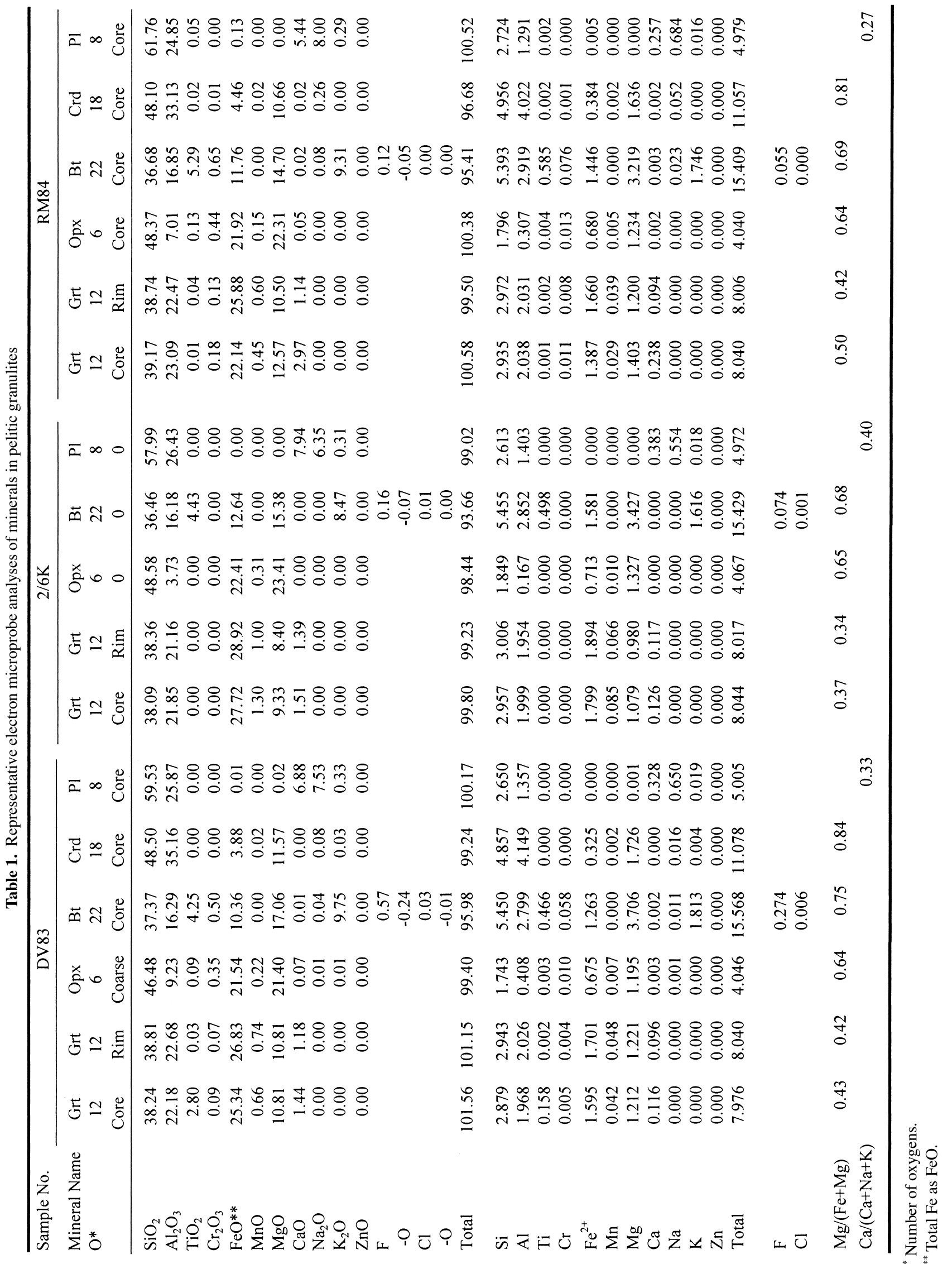




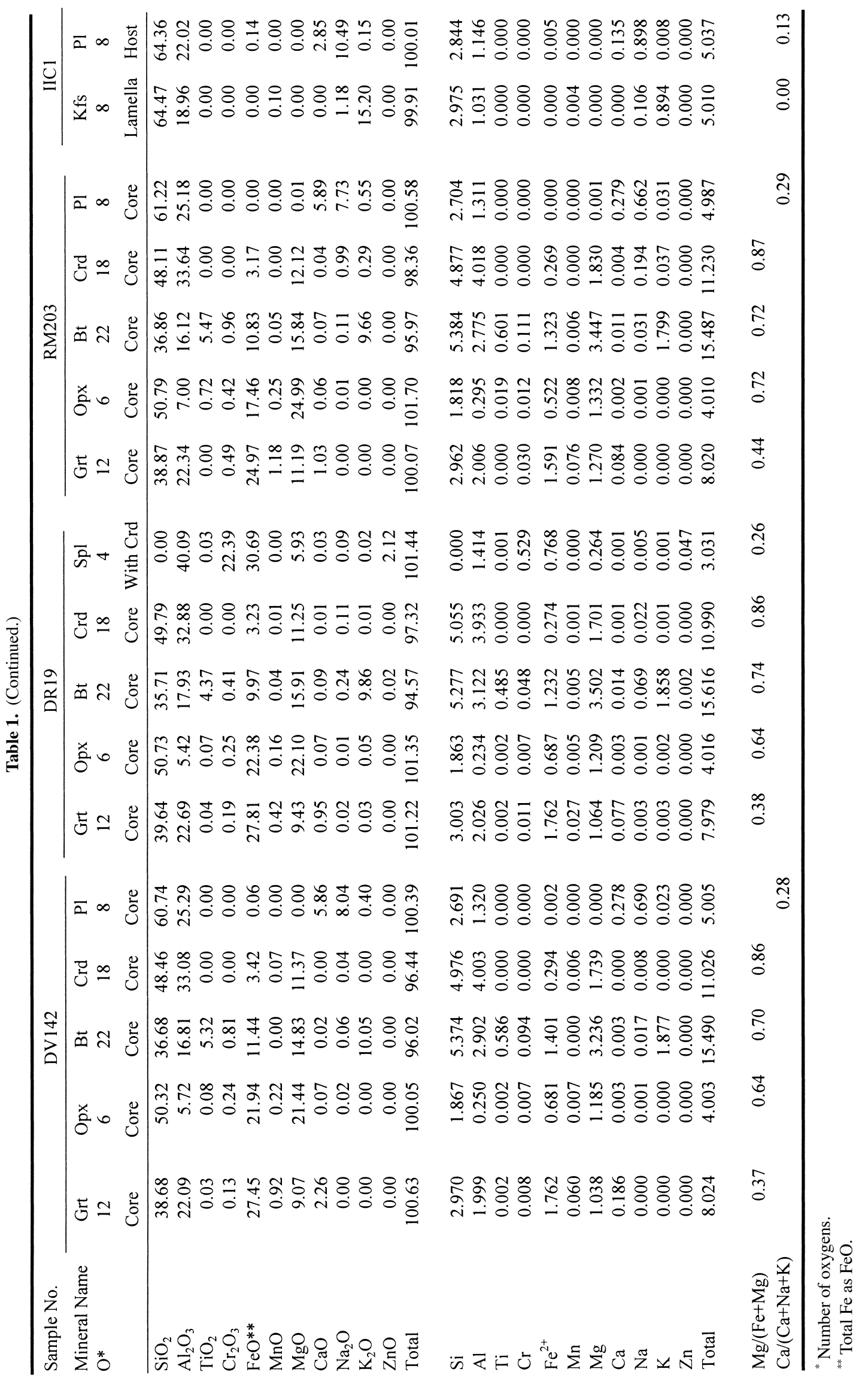



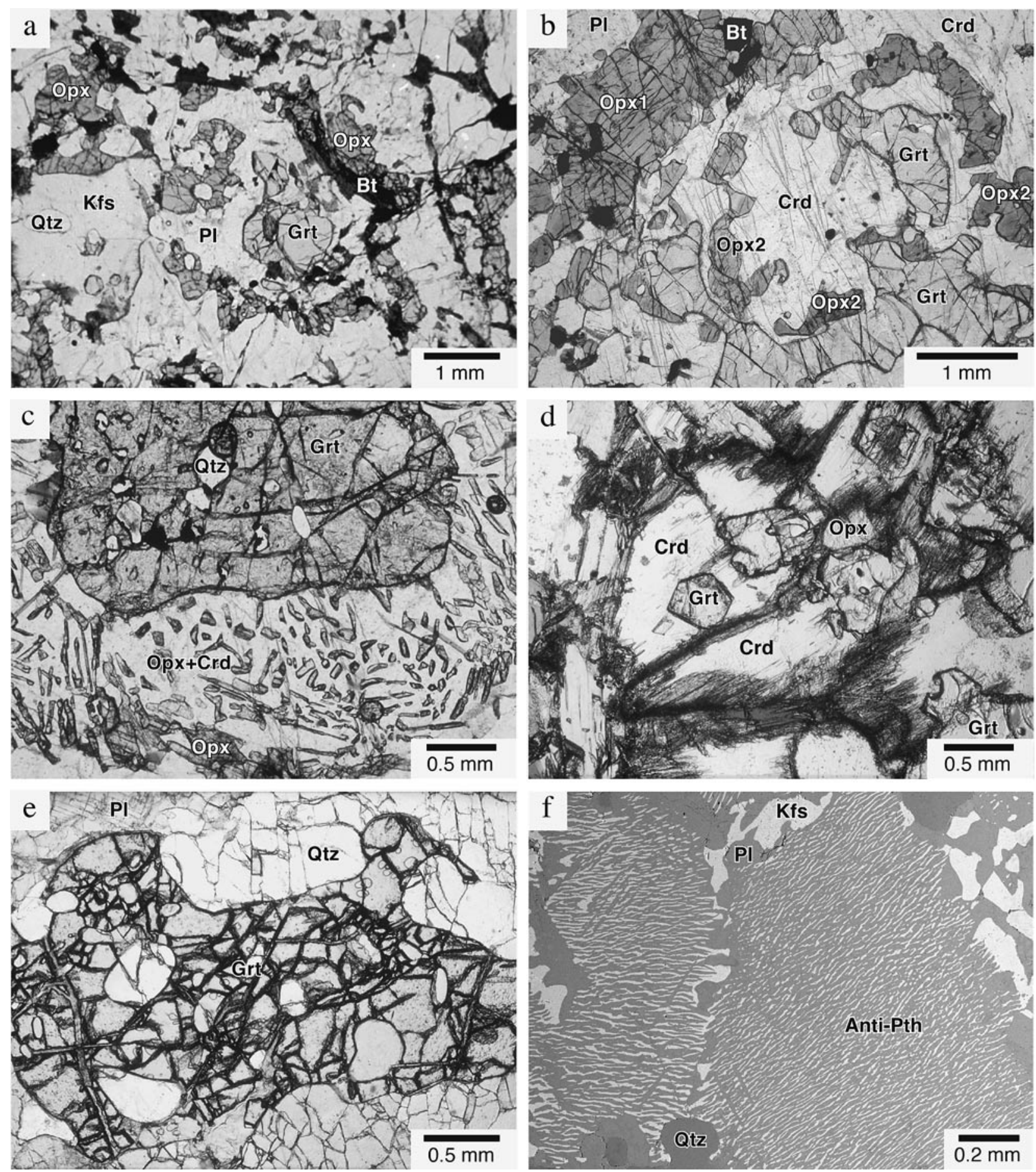

Figure 3. Photographs of examined pelitic granulites from the Southern Marginal Zone of the Limpopo Belt. (a) Garnet-orthopyroxene-biotite assemblage in cordierite-free pelitic granulite (sample 2/6A). (b) Garnet-orthopyroxene-cordierite-biotite assemblage in pelitic granulite (sample DV83). Opx1, coarse-grained subhedral orthopyroxene (earlier phase); Opx2, medium-grained anhedral orthopyroxene (retrograde phase). (c) Orthopyroxene + cordierite symplectite after coarse-grained garnet (sample DV56). (d) Cordierite corona around garnet (sample 2/6H). (e) Anhedral garnet in leucocratic rock (sample 2/6C). (f) Back scattered image photograph of coarse-grained antiperthite (Anti-Pth) in leucocratic gneiss (sample IIC1). 

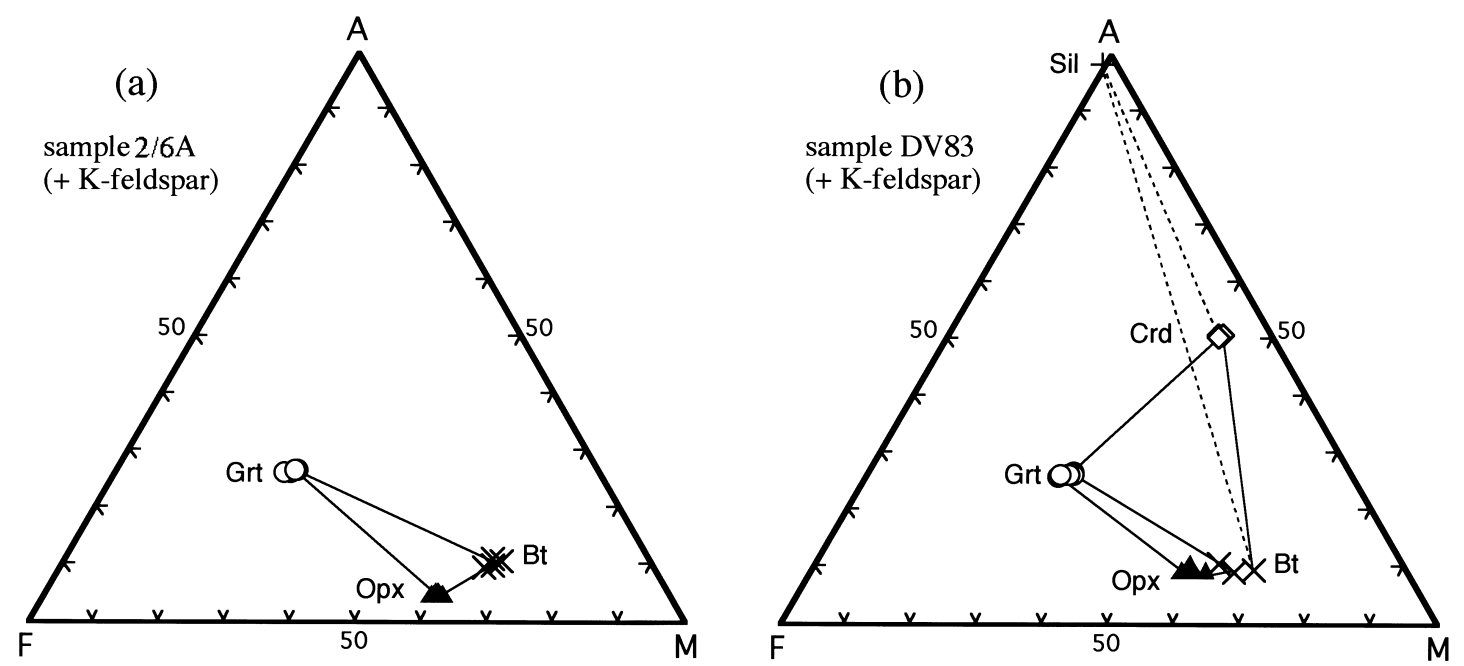

Figure 4. AFM diagrams (+ K-feldspar) showing mineral assemblages in representative pelitic granulites from the Southern Marginal Zone of the Limpopo Belt. (a) cordierite-free assemblage (sample 2/6A), (b) cordierite-bearing assemblage (sample DV83). Dashed lines indicate retrograde assemblages.

coarse-grained (up to $2.2 \mathrm{~mm}$ ) and coexists with garnet, biotite, cordierite, plagioclase, and quartz (Fig. 3b). There are two orthopyroxene varieties in the sample. Coarsegrained subhedral orthopyroxene generally occurs around cordierite, suggesting its earlier origin. Medium-grained and irregular-shaped orthopyroxene forms aggregates with cordierite around anhedral garnet (Fig. 3b). The latter texture is a product of a common reaction in the SMZ reported by many authors, as described by

$$
\mathrm{Grt}+\mathrm{Qtz} \rightarrow \mathrm{Opx}+\mathrm{Crd}
$$

As the orthopyroxene + cordierite occurs on the lowpressure side of the reaction in $P-T$ space, the texture has been explained as a retrograde metamorphic feature of the SMZ during a post-peak uplifting stage. In some samples, a spectacular symplectite orthopyroxene + cordierite texture occurs around garnet (Fig. 3c), which can be also explained by the reaction (2). All the orthopyroxene varieties exhibit strong pleochroism due to its high $\mathrm{Al}$ content. The highest $\mathrm{Al}$ content (up to 9.2 wt. $\% \mathrm{Al}_{2} \mathrm{O}_{3}$ ) was obtained from the core of the coarse-grained orthopyroxene around cordierite in sample DV83. Medium-grained orthopyroxene, probably formed by the reaction (2) shows slightly lower $\mathrm{Al}_{2} \mathrm{O}_{3}$ as 6.8-7.1 wt.\%. The results suggest that early $P-T$ conditions may be preserved in core of coarse-grained orthopyroxene.

In some samples, garnet is typically irregular in shape and is occasionally rimmed by retrograde cordierite (Fig. 3d). This texture is a product of a common reaction in the SMZ, as described by

$$
\mathrm{Grt}+\mathrm{Sil}+\mathrm{Qtz} \rightarrow \mathrm{Crd}
$$

This texture also suggests a pressure decrease during retrograde metamorphism.

Perchuk et al. $(1997 ; 2000)$ reported the following reaction textures from pelitic granulites (e.g. sample DV81 in their paper) collected from adjacent area of our sample DV83.

$$
\begin{aligned}
& \mathrm{Crd} \rightarrow \mathrm{Grt}+\mathrm{Sil}+\mathrm{Qtz} \\
& \mathrm{An} \rightarrow \mathrm{Grt}+\mathrm{Sil}+\mathrm{Qtz}
\end{aligned}
$$

However, such reaction textures were not observed in our examined samples, probably because of different mineral assemblage and bulk chemistry. It has to be noted that Perchuk et al. (1997; 2000) identified the reactions (4) and (5) along garnet-cordierite and garnet-plagioclase grain boundaries, suggesting their retrograde origin during decompression. As this paper focuses on the peak $P-T$ conditions of the SMZ, we will not further discuss the retrograde reaction textures.

\section{Leucocratic gneiss}

Leucocratic gneiss occurs as layers or patches parallel to the foliation of host pelitic granulite. The width of the leucocratic layers varies from a few $\mathrm{cm}$ up to $1.2 \mathrm{~m}$. The rocks are medium- to coarse-grained and composed mainly of quartz, $\mathrm{K}$-feldspar, plagioclase, and garnet, with minor sillimanite, cordierite, and graphite (Fig. 3e). Foliation in the rock is not obvious.

Two samples of antiperthite-bearing leucocratic gneiss (samples A7 and IIC1) collected from Bande- 
lierkop Quarry were examined in this study. A detailed petrological study of granulites in the quarry by Stevens and van Reenen (1992b) identified five distinct types of leucosome (L1 to L5). Sample A7 corresponds to L2, and sample IIC1 corresponds to L3 according to their classification scheme. L2 and L3 are both regarded as partialmelting products derived from host pelitic rocks, crystallizing during prograde to peak metamorphism of the SMZ. The leucosomes are composed mainly of quartz, $\mathrm{K}^{-}$ feldspar, and plagioclase with or without garnet, sillimanite, cordierite, and graphite.

Antiperthitic plagioclase is medium- to coarsegrained $(0.5-8 \mathrm{~mm})$ and composed of host albite and lamella orthoclase. Figure $3 \mathrm{f}$ shows an example back-scattered image of antiperthite in sample IIC1. The host: lamella ratio varies from $3: 1$ (sample IIC1) to $5: 1$ (sample A7). The composition of host plagioclase is homogeneous and free of obvious compositional zoning. Lamellae $\mathrm{K}$-feldspar is also free of chemical variation within individual antiperthite grains.

\section{Geothermobarometry}

\section{Ternary feldspar geothermometer}

We applied ternary feldspar geothermometry using the antiperthite to obtain the peak metamorphic temperature. The technique involved the determination of early singlephase feldspar and the application of the thermometer following the method described by Hokada (2001). Figure 5 shows a ternary $\mathrm{An}-\mathrm{Ab}-\mathrm{Or}$ diagram with plots of the compositions of host plagioclase and lamella $\mathrm{K}$-feldspar, together with early single-phase feldspar inferred from host-lamella volume proportions estimated from backscattered images. Using the ternary feldspar geothermometer of Fuhrman and Lindsley (1988), we obtained a temperature range of ca. $920-960^{\circ} \mathrm{C}$ for the mesoperthite formation in an L3 leucosome (sample IIC1). Similar estimates were obtained for several other ternary feldspar geothermometers such as those of Kroll et al. (1993) and Elkins and Grove (1990). Application of the geothermometer using an L2 leucosome (sample A7) gave slightly higher temperatures of ca. $980^{\circ} \mathrm{C}$. The temperature range obtained in this study $\left(920-980^{\circ} \mathrm{C}\right)$ is higher than that reported previously for the SMZ.

\section{Al-solubility in orthopyroxene}

The $\mathrm{Al}$ content and $X_{\mathrm{Mg}}($ mole $\mathrm{Mg} /(\mathrm{Fe}+\mathrm{Mg}))$ of orthopyroxene coexisting with garnet, sillimanite (or cordierite), and quartz are potential indicators of $P-T$ conditions. Figure 6 shows an $X_{\mathrm{Mg}}$ vs. $X_{\mathrm{Al}}$ plot for selected orthopy-

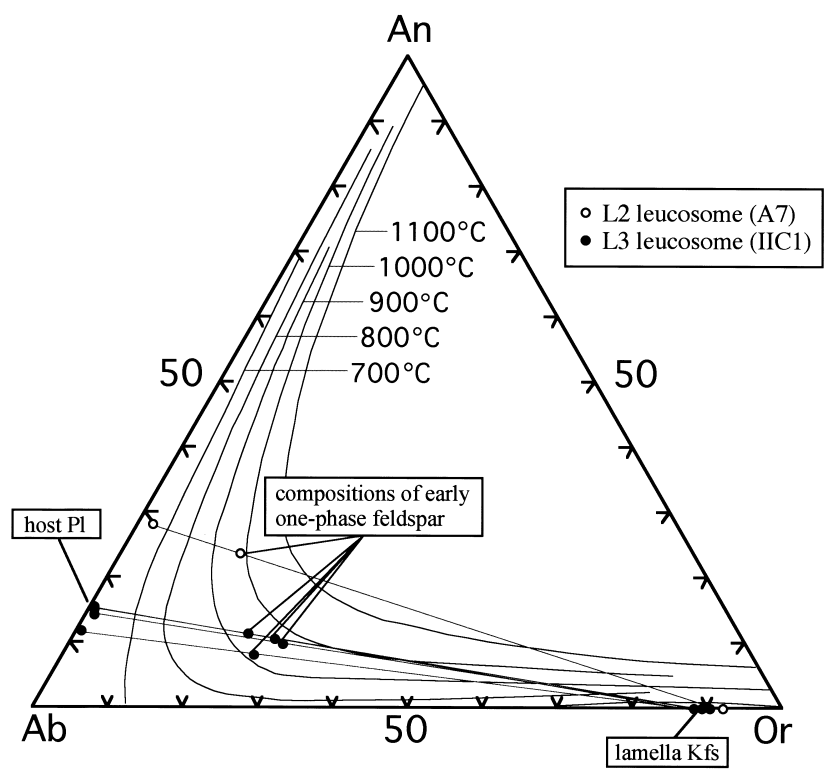

Figure 5. An- $\mathrm{Ab}-\mathrm{Or}$ diagram showing compositions of host plagioclase and lamella $\mathrm{K}$-feldspar together with early one-phase feldspar inferred from host-lamella volume proportions (see text for details). Ternary miscibility gaps are estimated for 8 kbar using the method of Fuhrman and Lindsley (1988).

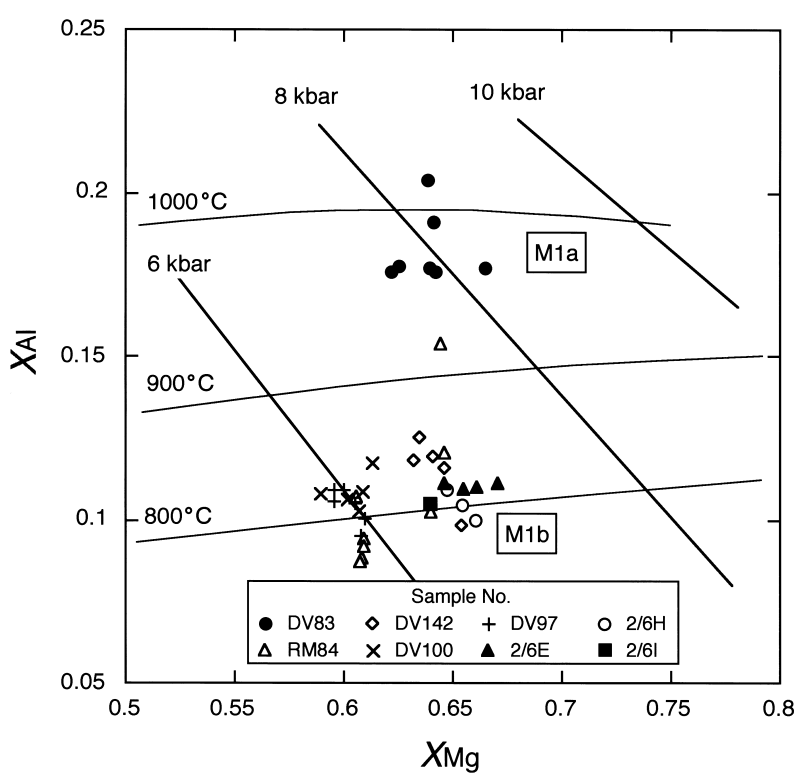

Figure 6. $X_{\mathrm{Mg}}$ vs. $X_{\mathrm{Al}}$ diagram showing compositions of orthopyroxene in pelitic granulites. $P-T$ grids are from Hensen and Harley (1990). M1a and M1b are discussed in the text.

roxenes in the pelitic granulite of the SMZ. Isotherms and isobars in the figure from the theoretical study by Hensen and Harley (1990) suggest that the coarse-grained orthopyroxene in pelitic granulite (sample DV83) equilibrated in a $P-T$ range of $970-1020^{\circ} \mathrm{C}$ and $7.6-8.3 \mathrm{kbar}$. The $X_{\mathrm{Mg}}$ isopleth of garnet in the assemblage indicates a slightly lower pressure of $7 \mathrm{kbar}$, probably due to faster 


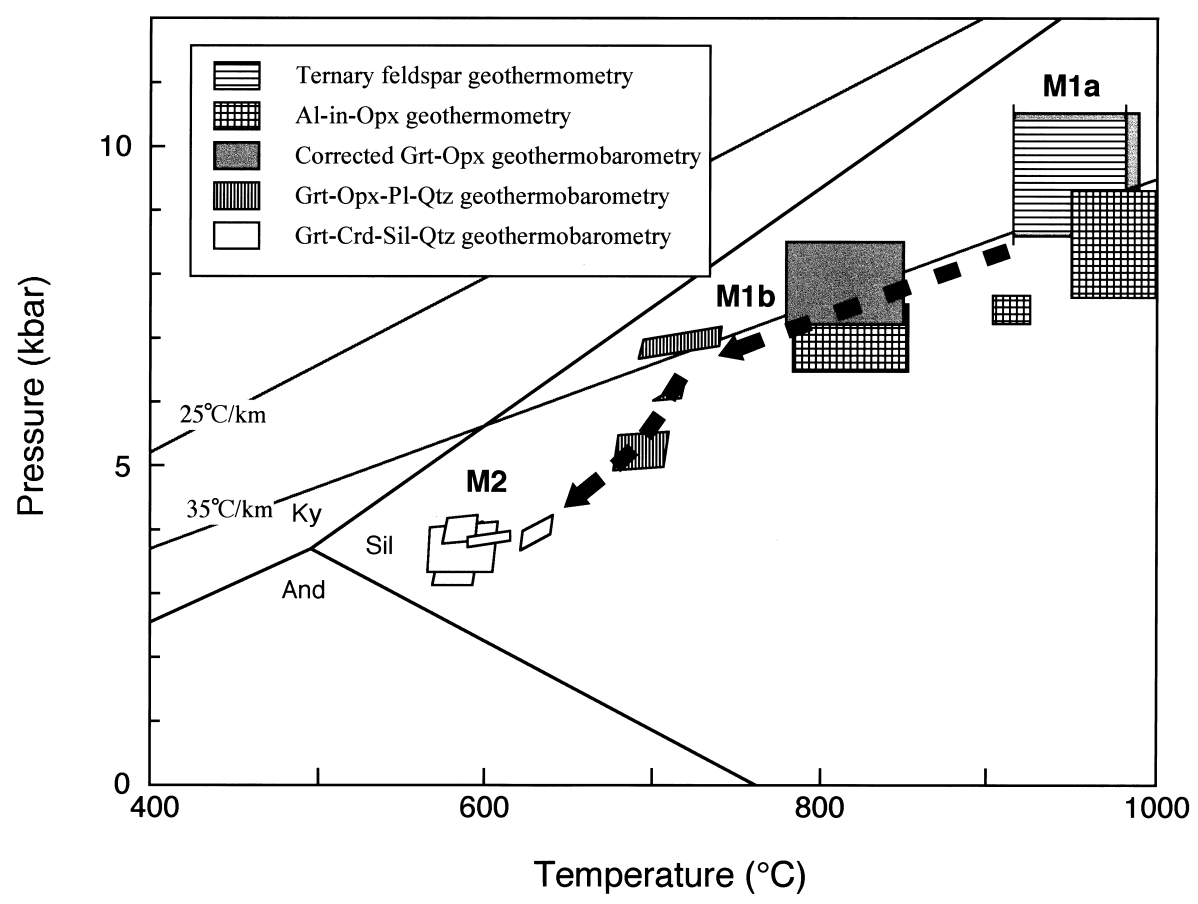

Figure 7. $P-T$ diagram showing metamorphic $P-T$ conditions and trajectory of the Southern Marginal Zone of the Limpopo Belt. Phase relations of aluminosilicates are based on thermodynamic data of Helgeson et al. (1978).

$\mathrm{Mg}$ diffusion within garnet than orthopyroxene, or retrograde modification of garnet composition with the progress of reaction (2). Harley (1998) revised the isopleths of Hensen and Harley (1990) using new experimental results (e.g. Carrington and Harley, 1995). The estimated results using Harley's (1998) isopleths are about $50^{\circ} \mathrm{C}$ lower $\left(940-960^{\circ} \mathrm{C}\right.$ at $\left.8.4-8.8 \mathrm{kbar}\right)$ than those given by Hensen and Harley's (1990) method. Figure 7 shows the combined $P-T$ data calculated for all analyzed orthopyroxenes in various pelite samples. The reason for the wide temperature range is not known, but probably suggests the distribution of a wide range of $X_{\mathrm{Al}}$ and $X_{\mathrm{Mg}}$ under the control of bulk-rock chemistry.

\section{Revised garnet-orthopyroxene geothermometer}

A revised garnet-orthopyroxene geothermometer corrected for retrograde exchange has been proposed by Pattison et al. (2003), and calculations based on the revised geothermometer were performed in this study using the TWQ2.02b thermodynamic database, using the thermodynamic data of Berman and Aranovich (1996) with modification to incorporate the experiments of Aranovich and Berman (1997) on the Al-solubility of orthopyroxene (+garnet) in the Fe end-member system. In order to bring the equilibria to convergence, the $\mathrm{Fe}-\mathrm{Mg}$ ratios of ferromagnesian minerals were adjusted according to their modal abundances, although the effect of varying mineral modes on the $P-T$ estimates are rather small. The calculation was performed using the program "RCLC" devel- oped by the authors.

Application of the method to sample DV83 yielded very high $P-T$ conditions of $920-990^{\circ} \mathrm{C}$ at $8.6^{-10}-5 \mathrm{kbar}$. These results are consistent with those of Hensen and Harley (1990) and Harley (1998). However, pelitic granulites from other localities of the SMZ indicate only moderate $P-T$ conditions $\left(780-850^{\circ} \mathrm{C}\right.$ at $\left.7.2-8.5 \mathrm{kbar}\right)$, similar to the results using Hensen and Harley's (1990) Al-in-orthopyroxene geothermobarometry.

\section{Discussion}

Ultrahigh-temperature (UHT) metamorphic conditions of greater than $900^{\circ} \mathrm{C}$ (probably $T>950^{\circ} \mathrm{C}$ ) were obtained for the Limpopo SMZ using early compositions of antiperthite in quartzo-feldspathic gneisses and high- $\mathrm{Al}(>9$ wt.\%) orthopyroxene in pelitic granulite. The new metamorphic temperature estimates indicate that the true peak temperature of metamorphism (defined as M1a in this study) in this zone was more than $100^{\circ} \mathrm{C}$ higher than the previously reported peak conditions (M1b). However, there may be an argument that the peak metamorphic conditions of the $\mathrm{SMZ}$ should be lower than ca. $870^{\circ} \mathrm{C}$ because of the lack of abundant dehydration melting reactions of biotite to form orthopyroxene $+\mathrm{K}$-feldspar + melt. It should also be noted that partitioning of $\mathrm{OH}$ by fluorine can expand the stability of biotite to higher temperatures (e.g. Hensen and Osanai, 1994). Recently, Motoyoshi and Hensen (2001) reported biotites with very high fluorine (up to $9 \mathrm{wt} \%$ ) in an aluminous granulite 
from the UHT $\left(T>1100^{\circ} \mathrm{C}\right)$ Napier Complex in East Antarctica. Tsunogae et al. (2003a) also noted high fluorine (up to $2 \mathrm{wt. \% )}$ pargasites in mafic and ultramafic granulites from Tonagh Island in the same complex. Therefore, it is not surprising that hydrous minerals such as biotite and hornblende are common in SMZ lithologies. As biotite in pelitic granulites of the SMZ (e.g. sample DV83) contains up to $0.6 \mathrm{wt} . \%$ fluorine in its crystal structure, a maximum temperature of more than $950^{\circ} \mathrm{C}$ may not be an unreasonable condition for the peak metamorphism of the SMZ.

It is also possible that the $P-T$ data from mesoperthite may represent the temperature of external melt, and therefore may not be indicative of the Limpopo peak metamorphism. In this study, we examined more than 200 thin sections from the SMZ and found that sillimaniteand/or cordierite-bearing leucosomes occur only as leucocratic lenses or layers in pelitic granulite, but not in mafic, tonalitic, and granodioritic gneisses. This suggests that sillimanite- and/or cordierite-bearing leucosomes are partial-melt products derived from pelitic granulites. This is consistent with the observation of Stevens and van Reenen (1992b) that most leucosomes in Bandelierkop Quarry are partial-melt products.

The three separate temperature calculations performed in this study yielded temperatures of more than $950^{\circ} \mathrm{C}$ as metamorphic conditions for SMZ lithologies. We therefore conclude that the peak temperature of the SMZ was more than $950^{\circ} \mathrm{C}$ (M1a). Such UHT conditions in one of the oldest granulite belts in the world provides rare and valuable information on the temperatures of 2.7 Ga continental lower crust. The estimated geothermal gradient of the thickened continental crust based on these results is as high as $35^{\circ} \mathrm{C} / \mathrm{km}$ at the time of peak metamorphism, which may be characteristic of late-Archean hot continental crust. Although no typical UHT assemblages such as sapphirine + quartz, spinel + quartz, and osumilite have been identified in granulites of the SMZ, the occurrence of such assemblages is restricted to $\mathrm{Mg}-\mathrm{Al}$ granulites (Harley, 1998), which are absent in the SMZ.

The M1a peak UHT event was probably followed by near-isobaric cooling toward the closure temperature of cation exchange geothermometers (M1b: $750-850^{\circ} \mathrm{C}$ at $7-$ $8 \mathrm{kbar}$ ), which has been regarded as the peak $P-T$ condition of the zone to date (e.g. van Reenen, 1983; Tsunogae and Miyano, 1989; Stevens and van Reenen, 1992a; Perchuk et al., 1996; 2000). The near-isobaric cooling process could be supported by the distribution of plotted $X_{\mathrm{Al}}$ and $X_{\mathrm{Mg}}$ values of orthopyroxene in various pelite samples, which are distributed near parallel to the temperature axis (see Fig. 6). However, there is no strong textural evi- dence to support near-isobaric cooling prior to M1b. Further detailed petrographical studies on various granulite lithologies are necessary to clarify this issue.

Subsequent to the M1b conditions, the rocks will have progressed through the M2 low-pressure condition evidenced by reactions (2) and (3), probably associated with exhumation. The retrograde path is consistent with that established by Tsunogae and Miyano (1989) based on geothermobarometry using garnet + orthopyroxene + cordierite + sillimanite + quartz assemblages in pelitic granulite. Recent $P-T$ paths reported by Perchuk et al. (1996; 2000) and Smit et al. (2001) for the SMZ based on detailed compositional analyses of minerals considering retrograde diffusion also support a decompression cooling path down to around the triple point of aluminosilicates.

A similar UHT condition of $T=900-1000^{\circ} \mathrm{C}$ at 8 kbar was also obtained for the NMZ of the Limpopo Belt in Zimbabwe based on mesoperthite in orthopyroxenebearing leucosomes associated with granulite-facies metamorphism of the zone (Tsunogae et al., 2001). Pelitic granulites of the NMZ also exhibit M2 garnet breakdown (reaction (2)) similar to that seen in the SMZ (e.g. Tsunogae et al., 1992). The present results suggest that the two zones underwent a similar metamorphic evolution: UHT metamorphism followed by isobaric cooling and decompressional cooling along clockwise $P-T$ path. This is consistent with previous tectonic discussions of the Limpopo Belt, which have concluded that both the SMZ and NMZ are high-grade equivalents of adjacent low-grade craton lithologies, formed by collision of the two Archean cratons (e.g. van Reenen et al., 1987; Roering et al., 1992). The present results therefore further support that the SMZ and NMZ have similar tectonic evolution histories.

The heat source of the UHT metamorphism is still not known. Kramers et al. (2001) discussed that the peak $P-T$ condition of the SMZ obtained by Stevens and van Reenen (1992) is much above reasonable steady state geotherm, and the peak condition could only have been attained through transient very high basal heat flux. In this study, we obtained even higher peak temperature conditions for the SMZ. Recent fluid inclusion studies on UHT granulites from the Napier Complex (e.g. Tsunogae et al., 2002; 2003b) suggest that very high-density carbonic fluid inclusions were trapped at the peak condition $\left(T>1000^{\circ} \mathrm{C}\right)$ of the complex, and the fluid could have transported heat from deeper level and given rise to UHT metamorphism. Such a process could have taken place also in the SMZ. Further detailed petrological study in conjunction with fluid activity will be topics of future research. 


\section{Acknowledgments}

This study commenced when the first author was a visiting research scientist at Rand Afrikaans University (RAU) during 2001-2002. His stay was supported by a grant to van Reenen from the NRF in South Africa and by the Department of Geology (RAU). Special thanks are due to Prof. N. J. Beukes at RAU for his support. Further funding was supported by the University of Tsukuba Project Research (Gakunai Project 2001 and 2003) to Tsunogae. We gratefully acknowledge the constructive reviews from Prof. L. L. Perchuk and Dr. M. Owada, and the editorial suggestions by Prof. M. Santosh on an earlier version of the manuscript.

\section{References}

Aranovich, L.Y. and Berman, R.G. (1997) A new garnet-orthopyroxene thermometer based on reversed $\mathrm{Al}_{2} \mathrm{O}_{3}$ solubility in $\mathrm{FeO}-\mathrm{Al}_{2} \mathrm{O}_{3}-\mathrm{SiO}_{2}$ orthopyroxene. American Mineralogist, $82,345-353$.

Barton, J.M., Jr. and van Reenen, D.D. (1992) When was the Limpopo Orogeny? Precambrian Research, 55, 7-16.

Barton, J.M., Jr., Doig, R., Smith, C.B., Bohlender, F. and van Reenen, D.D. (1992) Isotopic and REE characteristics of the intrusive charnoenderbite and enderbite geographically associated with the Matok Pluton, Limpopo Belt, southern Africa. Precambrian Research, 55, 451-467.

Berman, R.G. and Aranovich, L.Y. (1996) Optimized standard state and mixing properties of minerals: I. Model calibration for olivine, orthopyroxene, cordierite, garnet and ilmenite in the system $\mathrm{FeO}-\mathrm{MgO}-\mathrm{CaO}-\mathrm{Al}_{2} \mathrm{O}_{3}-\mathrm{SiO}_{2}-\mathrm{TiO}_{2}$. Contributions to Mineralogy and Petrology, 126, 1-24.

Carrington, D.P. and Harley, S.L. (1995) Partial melting and phase relations in high-grade metapelites: an experimental petrogenetic grid in the KFMASH system. Contributions to Mineralogy and Petrology, 120, 270-291.

Condie, K.C. (1997) Plate tectonics and crustal evolution (fourth edition). pp. 282, Butterworth Heineman.

Du Toit, M.C., van Reenen, D.D. and Roering, C. (1983) Some aspects of the geology, structure and metamorphism of the Southern Marginal Zone of the Limpopo Metamorphic Complex. Special Publication of the Geological Society of South Africa, 8, 121-142.

Elkins, L.T. and Grove, T.L. (1990) Ternary feldspar experiments and thermodynamic models. American Mineralogist, 75, 544559.

Ernst, W.G. (1972) Occurrence and mineralogic evolution of blueschist belts with time. American Journal of Science, 272, 657-668.

Frost, B.R. and Chacko, T. (1989) The granulite uncertainty principle: limitations on thermobarometry in granulites. Journal of Geology, 97, 435-450.

Fuhrman, M.L. and Lindsley, D.H. (1988) Ternary-feldspar modeling and thermometry. American Mineralogist, 73, 201215.

Harley, S.L. (1998) On the occurrence and characterization of ultrahigh-temperature crustal metamorphism. In What Drives Metamorphism and Metamorphic Reactions? (Treloar, P.J. and O'Brian, P.J. Eds.). pp. 286, Geological Society of London, Special Publication, 138, 81-107.

Helgeson, H.C., Delany, J.M., Nesbitt, H.W. and Bird, D.K. (1978) Summary and critique of the thermodynamic properties of rock-forming minerals. American Journal of Science, 278-A, 1-229.

Hensen, B.J. and Harley, S.L. (1990) Graphical analysis of $P-T^{-}$ $X$ relations in granulite facies metapelites. In High-temperature metamorphism and crustal anatexis (Ashworth, J.R. and Brown, M. Eds.). pp. 407, Kluwer Academic Publishers, The Netherlands, 19-56.

Hensen, B.J. and Osanai, Y. (1994) Experimental study of dehydration melting of $\mathrm{F}$-bearing biotite in model pelitic compositions. Mineralogical Magazine, 58A, 410-411.

Hokada, T. (2001) Feldspar thermometry in ultrahigh-temperature metamorphic rocks: Evidence of crustal metamorphism attaining $\sim 1100^{\circ} \mathrm{C}$ in the Archean Napier Complex, East Antarctica. American Mineralogist, 86, 932-938.

Jaques, A.L. and Green, D.H. (1980) Anhydrous melting of peridotite at $0-15 \mathrm{~kb}$ pressure and the genesis of tholeiitic basalts. Contributions to Mineralogy and Petrology, 73, 287310.

Kramers, J.D., Kreissig, K. and Jones, M.Q.W. (2001) Crustal heat production and style of metamorphism: a comparison between two Archean high grade provinces in the Limpopo Belt, southern Africa. Precambrian Research, 112, 149-163.

Kreissig, K., Holzer, L., Frei, R., Villa, I.M., Kramers, J.D., Kröner, A., Smit, C.A. and van Reenen, D.D. (2000) Geochronology of the Hout River Shear Zone and the metamorphism in the Southern Marginal Zone of the Limpopo Belt, Southern Africa. Precambrian Research, 109, 145-173.

Kretz, R. (1983) Symbols for rock-forming minerals. American Mineralogist, 68, 277-279.

Kroll, H., Evangelakakis, C. and Voll, G. (1993) Two-feldspar geothermometry: a review and revision for slowly cooled rocks. Contributions to Mineralogy and Petrology, 144, 510518.

Martin, H. (1993) The mechanisms of petrogenesis of the Archean continental crust - comparison with modern processes. Lithos, 30, 373-388.

Mason, R. (1973) The Limpopo Mobile Belt - southern Africa. Philosophical Transactions Royal Society London, A-273, 463-485.

Motoyoshi, Y. and Hensen, B.J. (2001) F-rich phlogopite stability in ultra-high-temperature metapelites from the Napier Complex, East Antarctica. American Mineralogist, 86, 14041413.

Pattison, D.R.M., Chacko, T., Farquhar, J. and McFarlane, C.R.M. (2003) Temperatures of granulite-facies metamorphism: constraints from experimental phase equilibria and thermobarometry corrected for retrograde exchange. Journal of Petrology, 44, 867-900.

Perchuk, L.L., Gerya, T.V., van Reenen, D.D., Safonov, O.G. and Smit, C.A. (1996) The Limpopo metamorphic complex, South Africa: Decompression/cooling regimes of granulites and adjusted rocks of the Kaapvaal Craton. Petrology, 4, 571599.

Perchuk, L.L., Gerya, T.V., van Reenen, D.D., Smit, C.A., Krotov, A.V. and Safonov, O.G. (2000) Comparable petrology and metamorphic evolution of the Limpopo (South Africa) and Lapland (Fennoscandia) high-grade terrains. Mineralogy and Petrology, 69, 69-107. 
Roering, C., van Reenen, D.D., Smit, C.A., Barton, J.M., Jr., de Beer, J.H., de Wit, M.J., Stettler, E.H., van Schalkwyk, J.F., Stevens, G. and Pretorius, S. (1992) Tectonic model for the evolution of the Limpopo Belt. Precambrian Research, 55, 539-552.

Smit, C.A., van Reenen, D.D., Gerya, T.V. and Perchuk, L.L. (2001) $P-T$ conditions of decompression of the Limpopo high-grade terrane: record from shear zones. Journal of Metamorphic Geology, 19, 249-268

Stevens, G. and van Reenen, D.D. (1992a) Constraints on the form of the $P-T$ loop in the Southern Marginal Zone of the Limpopo Belt, South Africa. Precambrian Research, 55, 279296.

Stevens, G. and van Reenen, D.D. (1992b) Partial melting and the origin of metapelitic granulites in the Southern Marginal Zone of the Limpopo Belt, South Africa. Precambrian Research, 55, 303-319.

Tsunogae, T. and Miyano, T. (1989) Granulite facies metamorphism in the Central and Southern Marginal Zones of the Limpopo Belt, South Africa. Journal of the Geological Society of Japan, 95, 1-16 (in Japanese with English abstract).

Tsunogae, T., Miyano, T. and Ridley, J. (1992) Metamorphic $P-T$ profiles from the Zimbabwe Craton to the Limpopo Belt, Zimbabwe. Precambrian Research, 55, 259-277.

Tsunogae, T., Nabara, A., Fukui, T., Harada, H., Mzvanga, W. and Mugumbate, F. (2001) Ultrahigh-temperature metamorphism of the Archean Limpopo Belt and its thermal effect on the adjacent low-grade Zimbabwe Craton, southern Africa. AGSO Geoscience Australia, Record 2001/37, 362-364.

Tsunogae, T., Santosh, M., Osanai, Y., Owada, M., Toyoshima, T. and Hokada, T. (2002) Very high-density carbonic fluid in- clusions in sapphirine-bearing granulites from Tonagh Island in the Archean Napier Complex, East Antarctica: implications for $\mathrm{CO}_{2}$ infiltration during ultrahigh-temperature $\left(T>1100^{\circ} \mathrm{C}\right)$ metamorphism. Contributions to Mineralogy and Petrology, 143, 279-299.

Tsunogae, T., Osanai, Y., Owada, M., Toyoshima, T., Hokada, T. and Crowe, W.A. (2003a) High fluorine pargasites in ultrahigh temperature granulites from Tonagh Island in the Archean Napier Complex, East Antarctica. Lithos, 70, 21-38.

Tsunogae, T., Santosh, M., Osanai, Y., Owada, M., Toyoshima, T., Hokada, T. and Crowe, W.A. (2003b) Fluid inclusions in an osumilite-bearing granulite from Bunt Island in the Archean Napier Complex, East Antarctica: implications for a decompressional $P-T$ path? Polar Geoscience, 16, 61-75.

van Reenen, D.D. (1983) Cordierite + garnet + hypersthene + biotite-bearing assemblages as a function of changing metamorphic conditions in the Southern Marginal Zone of the Limpopo Metamorphic Complex, South Africa. Special Publication of the Geological Society of South Africa, 8, 143167.

van Reenen, D.D. (1986) Hydration of cordierite and hypersthene and a description of the retrograde orthoamphibole isograd in the Limpopo belt, South Africa. American Mineralogist, 71, 900-915.

van Reenen, D.D., Barton, J.M., Jr, Roering, C., Smit, C.A. and van Schalkwyk, J.F. (1987) Deep crustal response to continental collision: The Limpopo belt of southern Africa. Geology, 15, 11-14.

(Manuscript received; 25 December, 2003)

(Manuscript accepted; 17 April, 2004) 